\title{
The Strategies for College English Teaching in the Big Data Era
}

\author{
Rui Xiang ${ }^{1, a}$ \\ ${ }^{1}$ Teaching and Researching Institute of Foreign Languages, Bohai University \\ 121000 Jinzhou Liaoning P.R. China \\ acynthiaxiang@hotmail.com
}

Keywords: Influences, Strategies, College English teaching, The big data era

\begin{abstract}
The influence of big data on college English teaching and learning is so profound that traditional teaching mode cannot meet today's students' needs. However, when big data brought about a lot of challenges for college English teachers and students, countless opportunities have been shown to us to transform college English teaching as well. Here a number of strategies are offered to improve college English teaching in the big data era.
\end{abstract}

\section{Introduction}

The term of "big data" was put forward by futurist Alvin Toffler in the early 1980s, who called big data for "the third wave's cadenza" in his book The Third Wave, and popularized by other specialists from IT industry. Big data includes data sets with sizes beyond the ability of commonly used software tools to capture, curate, manage, and process data within a tolerable elapsed time.[1] In bestseller Big Data, Mayer-Schönberger and Cukier offer a comprehensive and highly readable overview of the benefits and risks associated with big data, which they define as "the ability of society to harness information in novel ways to produce useful insights or goods and services of significant value.” [2] The big data doesn't use Stochastic analysis, instead all the data is analyzed and processed. Big data is being generated by everything around us at all times. Every digital process and social media exchange produces it. Systems, sensors and mobile devices transmit it. Big data is arriving from multiple sources at an alarming velocity, volume and variety.[3] Nowadays, this term has become a topic of conversation everywhere, more popularized and faster than any other technology-driven buzzword in recent history.

The application of cloud data, cloud computing, mobile Internet, smart phones, the net of things and Internet plus brings the society to a brand new era of big data. With the rapid development of theses advanced Internet technologies, big data led to a series of changes in our lives from almost every aspect, including people's life styles, behaviors, or even cognitive styles. With regard to college English learning, big data and ubiquitous Internet expands the quantity of information that college students have access to, including various information and diverse services of English learning. English learning is not restricted by time, space or even teachers any more. By contrast, the traditional classroom teaching modes seem outdated. Not only students but also teachers meet new challenges. Therefore, strategies for the challenges of big data on college English teaching are what we are hungry for. The integration of modern information technology and education is an evitable trend for college English teaching in the big data era.

\section{The Status Quo of College English Teaching in China}

Traditionally, teachers were the center and authorities in most classrooms ranging from primary 
schools to universities in China, while students were relatively passive. Gradually, Chinese educators and scholars found the weakness of such teaching modes, and in order to motivate students' activity and learning interest, they have been introduced many new teaching theories, teaching methods and multiple teaching aids to classrooms, especially in foreign language teaching. Take Bohai University as an example, multi-level teaching policy has been carried out in college English teaching since 2013. The situation has been changed to some degree, however, is far from perfect. Since restricted by teaching resources and teaching hours, most college English classes for non-English major students are big classes, in which teachers still play the dominated role in class, while students have very limited chance to practice their English. As a result, knowledge input is emphasized while ability training is undervalued, which hinders students from being qualified graduates with adequate English skills.

For the non-English major students, the most important goals of college English learning include their communicative ability in English, reading and writing ability in English. Without sufficient practice, language competence would not be possible. So we need to find out the problems first, and analyze them in order to get the problems solved. According to the survey we conducted, the aspects students think need improving are as follows: simple English learning environment(English class), inadequate interactivity in English class, few after-class activities, English contests that cover only a few top students, the selection of English reading materials, English writing class, ways of evaluation and the purpose of learning English.

\section{Influences on College English Teaching in the Big Data Era}

Influences on college students. Big data has permeated every level of the English learning system. Via the Internet, students have access to large quantity of information and services, including browsing weblogs, watching MOOCs and micro lectures offered by the best universities in the world, taking notes and submitting homework on line, and so on. The popularity of smart phones, pads and other mobile electronic terminals enables student to get information online at any time anywhere. Besides classes, textbooks and their English teachers, the traditional source for their English learning, students in the big data era have much more ways to get information on English learning. Moreover, they can choose what they are interested in and how long they learn according to their own learning habit after class, they even can get the latest information and technology. However, the overload information in the big data era makes students confused sometimes because it tends to be not easy to select the information they need. Screening information will be a big challenge for them.

Influences on college English teachers. In the big data era, English teachers seem to lose their advantages of English knowledge and skills since students can easily access to diverse English learning resources and services. Most of the students' learning problems can be solved by themselves with the aid of the Internet. It seems that teachers will be not necessary someday. In this case, the college English class will become a solo of English teachers with low interest audience, which will frustrate the teachers. So transformation of the traditional teaching mode in the classroom is urgently required.

In fact, to college students, English teachers are still indispensable. Although the large quantity English learning inform is available to college students, some of it is fragmental and disordered; it is difficult to insure the students' learning effect. So how to organize and integrate the information is also a challenge for students. The teachers of more experience and broaden horizon are needed. What new era calls for is the change of teachers' role, that is, the teachers are required to play a leading role instead of a dominated authority in the new type of class. To be specific, teachers used 
to be the information provider, but now the teachers have to help students reorganize and integrate diverse information they may be exposed to into a personalized and effective learning system.

In addition, to integrate information technology into English teaching requires teachers' ability to master some educational technology. To a large number of English teachers with no such education background it is not easy for them to master the updated technology.

Therefore, effective strategies are needed to deal with the challenges that both the students and teachers meet.

\section{Strategies for College English Teaching in Big Data Era}

Make English classes transformed and active. Improving the class teaching mode has been a heated topic in education. A new class teaching mode, transformed and active class, was introduced by Bohai University to cultivate college students' critical thinking capacity, creativity and practical abilities, which are key strengths for today's graduates in the big data era. English classes will be transformed from teachers-centered class to students-oriented class, from knowledge input emphasized class to ability valued class by changing cramming method to heuristic, inquiring, discussion-based, or case-based method. [4]

TBI(task based instruction), which is a learner-oriented teaching approach, is adopted in the new classes. Teachers design practical tasks for students to fulfill, and teachers teach only the essential and ensure plenty of practice and interaction. In class, English teachers should not only interact with students, but also lead students to interact with their peers. During the process of task fulfilling, students are in fact learning by doing. The practical tasks enable them to communicate with others, and make language in the classroom truly communicative, rather than the pseudo-communication that results from classroom activities with no direct connection to real-life situations. By doing this, students get the sense of achievement and are motivated and more involved in class. Thus, students find the value and irreplaceability of English class, and the learning objectives will be attained through teachers and students' joint work.

Build a ubiquitous English learning environment. In big data era, it is necessary to build a ubiquitous English learning environment for both teachers and students and it is not difficult to achieve this with the popularity of the Internet, smart phones and computers. The idea of transformed and active class mentioned above includes two types of classes. The first one is the class take in the classroom and the other one refers to after-class curriculums. In terms of English learning, if we combine the two types of classes with the assistance of Internet technology and big data concept, we can build a ubiquitous English learning environment for college students.

Take Bohai University for example, besides active class in the traditional form, Longman English Interactive platform was introduced to college English teaching. The platform covers the functions of "teaching, learning, management, test, evaluation and research". It offers sets of open courses, which can be rearranged by teachers according to different teaching objectives. With regard to students, they can decide the specific time and flow of their English learning, improve spoken English, writing skill by submitting practice or homework. On this platform, students can also discuss with others and get feedback from both the system and teachers. They have the right to set the general schedule for students, to assign homework, to give feedback to students, and to monitor the learning records of every student, by which they can optimize their teaching in accordance with the learning effect of her students.

In addition to this online learning platform, students are led to participate in kinds of English clubs and contests. With the help of Internet, we can involve a large number of students in an online activity. Many high-level English contests set online contest to popularize itself as well as to get 
more students involved.

Offer more personalized English learning system. According to SLA researches, linguists found language acquisition follows natural law, under which different learners' learning paths are almost the same. The well known input hypothesis states that learners progress in their knowledge of the language when they comprehend language input that is slightly more advanced than their current level. Krashen called this level of input " $i+1$ ", where "I" is the learner's interlanguage and “ +1 ” is the next stage of language acquisition.[5]

However, in college English classes, student have different language levels, if we input language of the same level, it is impossible to meet students' language level or next level, that is, it is impossible to satisfy every student's learning demand. Personalized education is definitely an ideal form of language teaching. However, it could not be implemented in most stated universities in the old days, because it requires a lot more teaching resources. But now in the big data era, with the assistance of the Internet and various English learning resources, it is more likely for educators to design and offer personalized English learning system.

First, in terms of the English teaching resource, diverse and multi-dimension teaching materials, such as text, video and audio files, multimedia courseware, e-portfolio, online resource database, English learning software, and English learning websites and so on, are the trend of the future. For instance, various English learning apps, ranging from the spoken English practice to words training, are developed and available in smart phones. Since practices of different levels are provided in many of the apps, teachers can select different practice for students of different level. Many of these apps are designed full of fun, such as Fun Dubbing, Fluent English, which increase the enjoyment of English learning.

Second, for students of different language levels, they are evaluated respectively. Multi dimensional assessment is part of personalized learning system. Teachers' review, peer review, and system review are adopted to evaluate students. The assessment system attaches more importance to process evaluation, which show the differences among students.

Third, with regard to the way of monitoring learning process, besides online learning platform, the popularity of social network helps teacher communicate with students after class. QQ and Wechat are the top two social software college students use. A QQ or Wechat group is important communicative channel, so keeping the line of communication open is vital for the relationship between teachers and students.

Enhance teachers' comprehensive capacity. The big data era brings more learning opportunities and learning methods to learners, while it sets higher requirements for college English teachers. To meet the new challenges in the big data era, college English teachers have to promote their comprehensive capacity, or else they would be eliminated by the new society.

To begin with, their ability to distinguish useful information from large quantity of that is necessary. In such an era of information explosion, students are confused by the overwhelming information they are exposed to. It should be teachers who help students select the valuable information.

Furthermore, teachers have to enhance their ability to use information technology. Through online learning platform, teachers can gain data of students, and they should learn to collect, read and analyze these data to find out information of their students, such as their English level, their cognitive style, their preference, their learning hours, their weakness and their strengths. Only keeping the key information in mind can teachers design the best teaching plan for students.

In addition, teachers have to keep in pace with the latest educational theory and technology. Lifelong learning is the evitable trend for people in the new era, especially for teachers. In the big 
data era, teachers can promote themselves by learning from the high-quality classes, which are available on line, participating in academic communication, professional training, writing self reflection logs, and researching.

College English teachers should raise the awareness of self development, while universities and government should also value the development and growth of teachers, provide teachers with more opportunities.

\section{Summary}

Big data is still new to us, whose influences on college English education just begin, and more profound influences will be likely shown in the near future. Every time we type, every time we click is producing data. Insights from big data can enable all teachers to make better decisions-deepening students' engagement, optimizing teaching operations and monitoring the learning process of students. However, we have a long journey to go. There are still lots of questions that need solving and researching. Big data transformed the form of class teaching, the role of English teachers, the concept and even purpose of learning English. It will inspire us to explore more, and research further, explaining how to deal with the challenges it brings.

\section{Acknowledgements}

This paper is one of the researching achievements for Bohai University Teaching Reform Project in 2014(project number: BDJG-14-QN-C-009) and Project of Liaoning Provincial Education and Science “12th Five-Year Plan” in 2015 (project number: JG15DB038)

\section{References}

[1] C. Snijders,, U. Matzat, U.-D. Reips, “'Big Data': Big gaps of knowledge in the field of Internet”. International Journal of Internet Science 7(2012): 1-5.

[2] V. Mayer-Schönberger, , K. Cukier, Big Data: A Revolution That Will Transform How we Work, Live, and Think, John Murray, London, 2013.

[3] Information on http://www.ibm.com/big-data/us/en/

[4] L. L, Y.D. Yang, “On Transformed and Active Class”. Journal of Bohai University 6(2015):97.

[5] S. D. Krashen, The Input Hypothesis: Issues and Implications, Longman, London and New York, 1985. 